\title{
Optimal Battery Charger Fed by Photovoltaic System based on Decreased Charging Current Method
}

\author{
Hussain S. Maraud \\ Electrical Engineering Dep., \\ Faculty of Engineering, \\ Al-Mustansiriayah University \\ Baghdad, Iraq
}

\author{
Isam M. Abdulbaqi, PhD \\ Electrical Engineering Dep., \\ Faculty of Engineering, \\ Al-Mustansiriayah University \\ Baghdad, Iraq
}

\begin{abstract}
The charger is the most important part of the solar system because the only limited-age part of this system is the storage batteries. Storage batteries are essential in all standalone solar electric systems (PV power systems). Their efficiency and life time affects significantly the overall PV system performance and economics. The storage battery's effectiveness depends on the charging process. The maximum power point tracking (MPPT) technique is adopted to maximize the PV output power for any temperature and irradiation conditions.

This solar charging system is composed of a solar panel, leadacid batteries, buck converter as power charger circuit and a PIC81F45K22 microcontroller as a control unit.

The simulation results are achieved by using Simulink Proteus Isis Professional software. These results allowed to demonstrate the validity of the proposed charging technique. The battery charger prototype was tested and the results obtained allowed to conclude about the conditions of permanent control on the battery charger.
\end{abstract}

\section{Keywords}

Lead-Acid Battery, State of Charge, Photovoltaic System, MPPT, Optimal Battery Charger

\section{INTRODUCTION}

The objectives of this work are to design, simulate and analyze the operation of an optimal lead-acid battery charger supplied from a two (250W) nominal power, Photovoltaic (PV) panel connected in parallel to charge two $(12 \mathrm{~V}, 200 \mathrm{Ah})$ lead-acid batteries connected in series.

To make the PV system more stable, where the power produced by the photovoltaic panel is unstable and strongly related to the insolation intensity, operating temperature and other factors, it is important using the storage batteries, especially in stand-alone (i.e. not grid-connected) photovoltaic (PV) systems. So that, problem of surplus or reduction of the producing power can be solved [1]. Another purpose of using the batteries in the off-grid photovoltaic power system is to store the electrical energy produced by the PV panel during the sunshine period and restore it during night time, sunless periods and those of weak irradiation. More, energy storage devices plays a significant role in maintaining the dynamic power balance in the entire system, able to meet momentary peak power demands and hence, improves the reliability of these systems [2].

The lead acid battery, although known for more than one hundred years, is more commonly used in photovoltaic system due to its low cost, reliability, ease of availability, energetic efficiency, lifetime and maintenance-free operation [2].

The charge controller has been regarded as one of the important devices in photovoltaic systems to safely charge lead acid battery and improve charge efficiency. The most basic function of a charge controller is to prevent lead-acid battery from overcharging and deep discharging [2]. Besides that, the unstable voltage from PV system may damage the load. Also, studies have shown that the life time of the battery is degraded without using charge controller. Therefore, an optimal charge controller should be designed to prolong the battery's life time [1] [3].

A charge controller will sense the battery voltage, and reduce or stop the charge current when the charging voltage reaches specified level called gasing or overcharging level in which the electrolyte solution of a lead-acid battery starts to chemical decomposition and generates gases. This is especially important with sealed lead-acid battery, where replacement of electrolyte that is lost during overcharging is not possible [3].

\section{LEAD-ACID BATTERY}

\subsection{Lead-Acid Battery Chemical Theory}

The cell of a lead-acid battery comprises a set of positive and negative electrodes. In a full charge state, the positive electrode is lead dioxide $\left(\mathrm{PbO}_{2}\right)$ and the negative electrode is the sponge lead $(\mathrm{Pb})$ and the electrolyte solution is the sulfuric acid $\left(\mathrm{H}_{2} \mathrm{SO}_{4}\right)$ [4] [5]. For charging and discharging processes, the chemical reaction could convert the energy from electrical into chemical and back again. The following equation shows the process of a chemical reaction inside the battery during charging and discharging [4]:

$$
\mathrm{Pb}+\mathrm{PbO}_{2}+\mathrm{H}_{2} \mathrm{SO}_{4} \stackrel{\text { discharge }}{\stackrel{\text { charge }}{\longrightarrow}} 2 \mathrm{PbSO}_{4}+2 \mathrm{H}_{2} \mathrm{O}
$$

The nominal potential of each $\mathrm{Pb} / \mathrm{PbO}_{2}$ cell is about $2 \mathrm{~V}$. So, in order to prevent the overcharging and gassing problems, the cell is charged for less than $2.4 \mathrm{~V}$ which is known as the gassing voltage. The cell charging and discharging terminal voltage characteristic is shown in Fig. 1 [6].

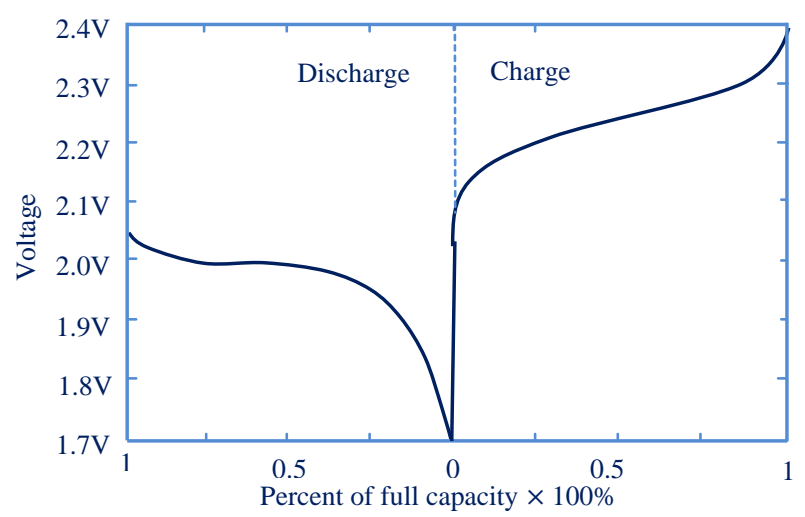

Fig. 1: Discharge and charge voltage of a lead-acid cell [6] 


\subsection{State of Charge and Depth of Charge}

State of charge (SOC) and depth of charge (DOC) are variables that can describe the battery charge. The main difference is that the SOC describes the ratio of the remaining charge $\left(\mathrm{Q}_{\mathrm{e}}\right)$ to the nominal capacity $\left(\mathrm{C}_{10}\right)$ of the battery, while the DOC represents the ratio of $\left(Q_{e}\right)$ to the actual capacity $\left(C_{I}\right)$ of the battery under a specific discharge current (I).

These two variables can be achieved by calculating the charge consumed and the battery capacity [5]

$$
\mathrm{SOC}=1-\mathrm{Q}_{\mathrm{e}} / \mathrm{C}_{10}
$$

$\mathrm{DOC}=1-\mathrm{Q}_{\mathrm{e}} / \mathrm{C}_{\mathrm{I}}$

Where:

$\mathrm{C}_{10}$ : is the battery nominal capacity ( $\left.\mathrm{Ah}\right)$

$\mathrm{C}_{\mathrm{I}}$ : is the battery actual capacity under the actual discharge current I (Ah)

$\mathrm{Q}_{\mathrm{e}}$ : is the charge consumed from the battery (Ah)

Knowing of SOC is very important in the charging process of a lead-acid batteries, because it determines the value of instantaneous charging current to prevent the overcharging and gassing problems. Where, as SOC is increased during the charging process, the charging current must be decreased gradually to overcome the gassing and electrolyte losses and to increase the useful service life for the battery [5].

\subsection{Electromotive Force of a Lead-Acid Battery}

The electromotive force or the open circuit voltage of a leadacid battery cell can be obtained by using the Nernst's equation. This equation written as [4] [6]:

$\mathrm{EMF}=2.01+0.0296 \ln \frac{\alpha^{2}\left(\mathrm{H}_{2} \mathrm{SO}_{4}\right)}{\alpha^{2}\left(\mathrm{H}_{2} \mathrm{O}\right)}$

Because the concentration or specific gravity (SG) of the electrolyte solution varies through the charging and discharging of the lead-acid battery, the relative activity $(\alpha)$ of $\mathrm{H}_{2} \mathrm{SO}_{4}$ will also be changed in the Nernst's equation. Due to this, the open circuit voltage of a lead-acid battery is directly proportionally with temperature and specific gravity of the electrolyte solution. Therefore, by knowing the open circuit voltage of lead-acid battery and temperature, SG of electrolyte solution can be determined and thus the state of charge can be determined. The graph in Fig. 2 shows the the relation between the electrolyte $\mathrm{SG}$ and the cell voltage at $25^{\circ} \mathrm{C}[4][6]$.

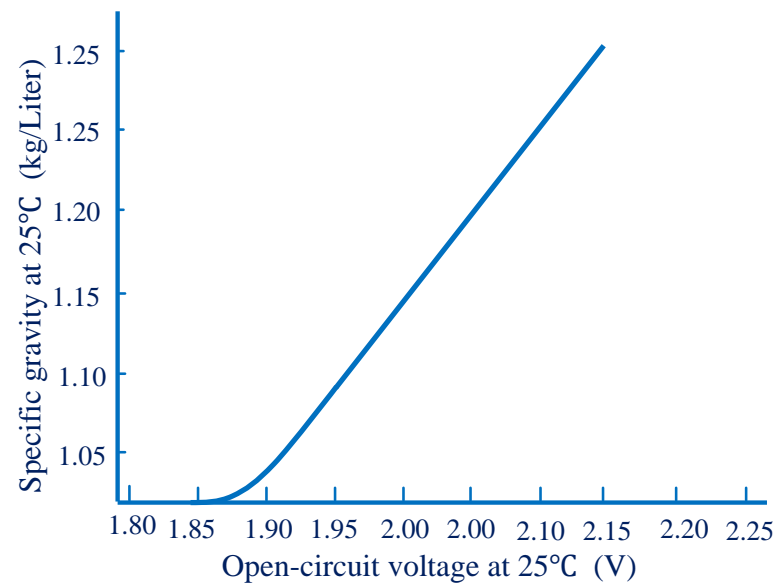

Fig. 2: Cell voltage as a function of $\mathrm{SG}$ at $25^{\circ} \mathrm{C}$ [4]

\subsection{Battery Modeling and Simulation}

The equivalent circuit of a lead-acid battery is based on nonlinear equations. The equivalent circuit consist of two main branches: a main branch which approximate the battery dynamics under most conditions, and a parasitic branch which accounte for the battery behavior at the end of the charging period. The equivalent circuit of the battery is shown in Fig. 3 [7] [8].

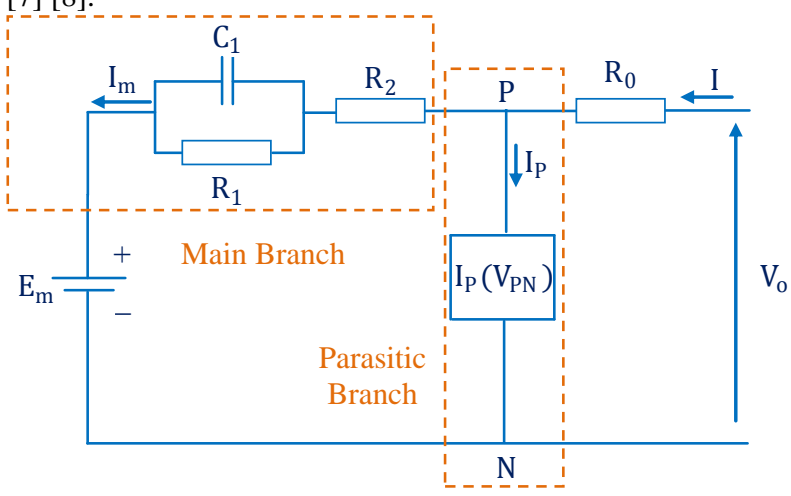

Fig. 3: Equivalent circuit of the lead-acid battery [8]

The values of $E_{m}, R_{0}, R_{1}, C_{1}, R_{2}$ and $I_{p}$ are determined from (5)-(10) with the given parameters.

$$
\begin{aligned}
& \mathrm{E}_{\mathrm{m}}=\mathrm{E}_{\mathrm{m} 0}-\mathrm{K}_{\mathrm{E}}(273+\theta)(1-\mathrm{SOC}) \\
& \mathrm{R}_{0}=\mathrm{R}_{00}\left[1+\mathrm{A}_{0}(1-\mathrm{SOC})\right] \\
& \mathrm{R}_{1}=-\mathrm{R}_{10} \ln (\mathrm{DOC}) \\
& \mathrm{C}_{1}=\tau / \mathrm{R}_{1} \\
& \mathrm{R}_{2}=\mathrm{R}_{20} \frac{\mathrm{e}^{\left[\mathrm{A}_{21}(1-\mathrm{SOC})\right]}}{1+\mathrm{e}^{\left(\mathrm{A}_{22} \mathrm{I}_{\mathrm{m}} / \mathrm{I}^{*}\right)}} \\
& \mathrm{I}_{\mathrm{P}}=\mathrm{V}_{\mathrm{PN}} \mathrm{G}_{\mathrm{P} 0} \exp \cdot\left(\frac{\mathrm{V}_{\mathrm{PN}}}{\mathrm{V}_{\mathrm{P} 0}}+\mathrm{A}_{\mathrm{P}}\left(1-\frac{\theta}{\theta_{\mathrm{f}}}\right)\right)
\end{aligned}
$$

Where:

$\mathrm{E}_{\mathrm{m}}$ : Battery cell voltage $(\mathrm{V})$

$\mathrm{E}_{\mathrm{mo}}$ : Battery cell voltage at full charge $(\mathrm{V})$

$\mathrm{K}_{\mathrm{E}}$ : Temperature coefficient of a battery cell $\left(\mathrm{V} /{ }^{\circ} \mathrm{C}\right)$

$\theta$ : Electrolyte temperature $\left({ }^{\circ} \mathrm{C}\right)$

$\theta_{\mathrm{f}}$ : Electrolyte freezing temperature $\left(-40^{\circ} \mathrm{C}\right)$

$\mathrm{V}_{\mathrm{PN}}$ : Parasitic branch voltage $(\mathrm{V})$

$A_{0}, A_{21}, A_{22}, A_{P}, G_{P 0}$ and $V_{\text {po }}$ are constants for a lead-acid battery. $\mathrm{R}_{00}, \mathrm{R}_{10}$ and $\mathrm{R}_{20}$ are parameters related to the state of health $(\mathrm{SOH})$ of battery and they do vary a little among different batteries built with the same technology. The values of this battery model parameters and constants are reported in Table 1 for the lead acid battery, $\mathrm{C}_{10}=500$ Ah capacity [7].

Table 1, Parameters of the Lead-Acid Battery model,

\begin{tabular}{|c|c|c|c|}
\hline Parameter & Value & Parameter & Value \\
\hline $\mathrm{E}_{\mathrm{mo}}$ & $2.18 \mathrm{~V}$ & $\mathrm{~A}_{22}$ & -8.45 \\
\hline $\mathrm{K}_{\mathrm{E}}$ & $0.84 \times 10-3 \mathrm{~V} /{ }^{\circ} \mathrm{C}$ & $\tau$ & $7200 \mathrm{~s}$ \\
\hline $\mathrm{R}_{00}$ & $2.0 \mathrm{~m} \Omega$ & $\mathrm{G}_{\mathrm{P} 0}$ & $2 \mathrm{Ps}$ \\
\hline $\mathrm{R}_{10}$ & $0.4 \mathrm{~m} \Omega$ & $\mathrm{A}_{\mathrm{P}}$ & 2.0 \\
\hline $\mathrm{R}_{20}$ & $15 \mathrm{~m} \Omega$ & $\mathrm{V}_{\mathrm{P} 0}$ & $0.1 \mathrm{~V}$ \\
\hline $\mathrm{A}_{0}$ & -0.20 & $\theta_{\mathrm{f}}$ & $-40^{\circ} \mathrm{C}$ \\
\hline $\mathrm{A}_{21}$ & -8.0 & & \\
\hline
\end{tabular}




\section{SOLAR CELL AND MAXIMUM POWER TRACKING}

\subsection{PV Cell Operation}

$\mathrm{PV}$ cell is basically a semiconductor $p-n$ junction-based photo diode as shown in Fig. 4 [9].

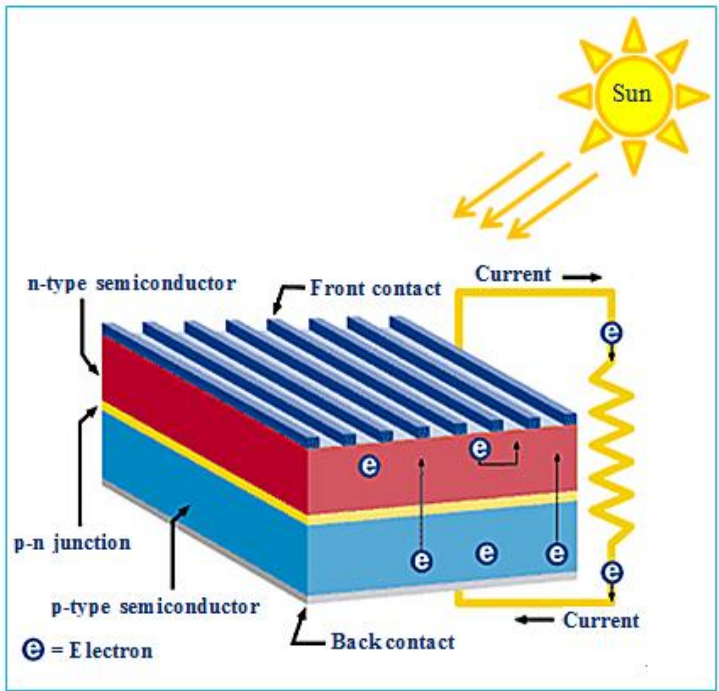

Fig. 4: PV cell configuration [9]

The operation principle of a PV cell relies on the principle of the photoelectric effect. This principle can be defined as a phenomenon in which an electron gets enough energy to jump from the valence band to the conduction band as a result of the absorption of sunlight by an either metallic or nonmetallic materials [10]. The light photons that have energy higher than the band-gap energy of photovoltaic material can make the electrons in that material separated from the atoms and creating a hole-electron pairs. Therefore, when sunlight exposes to a PV cell surface, some part of solar energy will be absorbed by the PV semiconductor. The electrons from the valence band jump to the conduction band of the semiconductor atoms in the case of the absorbed energy are greater than the band gap energy. These free electrons are now moving freely and can be forced to transfer a certain direction due to the action of the electric field presented in the photovoltaic cells. These flowing electrons comprise current and can be transmitted to the external circuit [10].

\subsection{Equivalent Circuit Model of a PV Cell}

The modeling of a PV cell can be achieved by connecting a DC current source in parallel with a diode. In addition to that, the model contains its own parallel and series resistances. Fig. 5 illustrates the equivalent circuit of a PV cell.

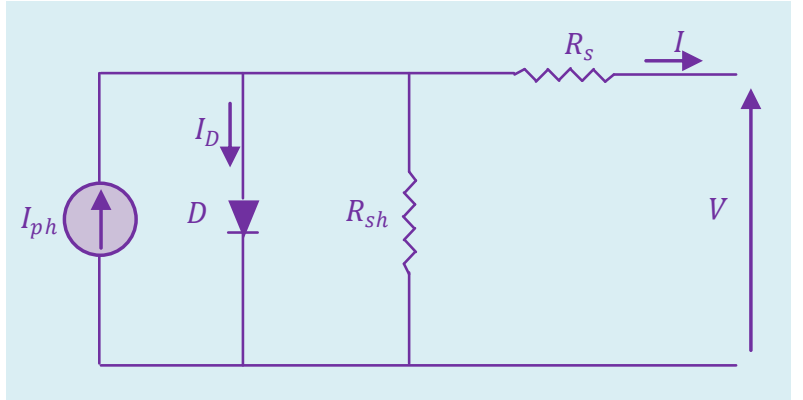

Fig. 5: The equivalent circuit of a PV cell [11]
$I-V$ characteristic equation of a PV cell is given as [11]:

$I=I_{p h}-I_{o}\left(e^{q V_{d} / K T A}-1\right)-\frac{V+I R_{s}}{R_{s h}}$

Where:

I: Cell output current (A)

$I_{p h}:$ Light-generated current or photocurrent (A).

$V$ : Cell output voltage (V).

$R_{s h}:$ Shunt resistance $(\Omega)$.

$R_{S}:$ Series resistance $(\Omega)$.

$I_{o}$ : Diode reverse saturation current $(\mathrm{A})$.

$q$ : Electron charge $\left(=1.6 \times 10^{-19}\right.$ Coulomb).

$V_{d}$ : Voltage across the diode $(\mathrm{V})$.

$K$ : Boltzmann's constant $\left(=1.38 \times 10^{-23} \mathrm{~J} / \mathrm{K}\right)$

$T$ : Cell temperature (K).

$A$ : Diode ideality constant.

\subsection{Maximum Power Point Tracking}

Fig. 6 illustrates the PV panel characteristics under different conditions of radiation intensity.

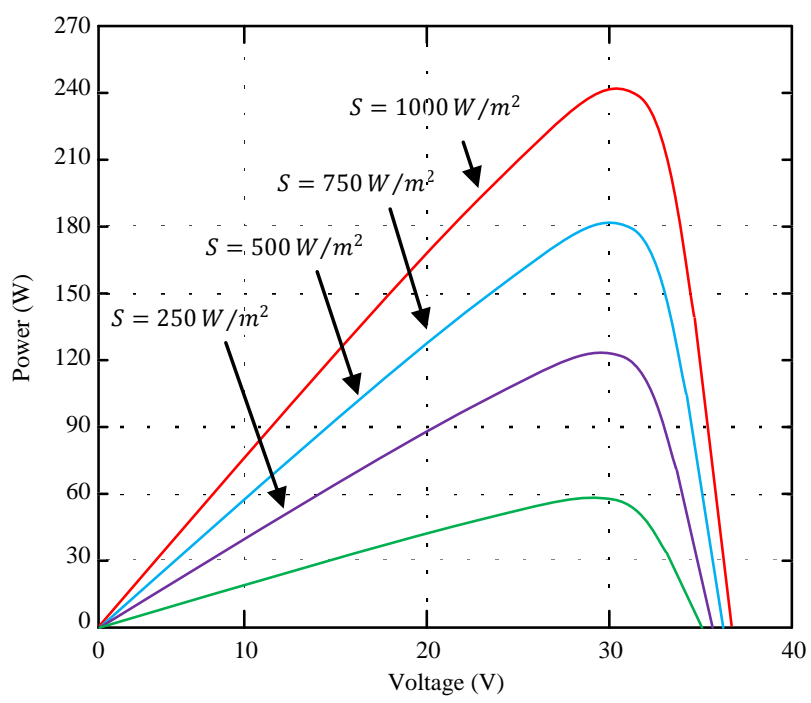

Fig. 6: P-V Characteristics of a PV panel for different values of solar irradiance $(S)$ at constant temperature [12]

From Fig. 6, it can be observed that each curve has a maximum power point (MPP) which is the optimal point for the efficient use of the PV panel. There are several of suggested maximum power point tracking (MPPT) algorithms to execute this process. These suggested methods differ in popularity, complexity, cost, sensors needed, and convergence speed and other aspects. Mostly, the MPPT methods can be classified into two main classes [13]:

1) Direct methods: These MPPT algorithms do not depend on the foreknowledge of PV panel characteristics. This class of MPPT methods includes following algorithms:

- Perturb and Observe method (P\&O)

- Incremental conductance method (INCond.)

- Fuzzy logic method

- Neural network method

2) Indirect methods: These methods require foreknowledge of PV panel; where, it depends on mathematical relations gained from empirical data of PV panel that used. This class of MPPT methods includes following algorithms: 
- Look-up table method

- Open-circuit PV voltage method

- Short circuits PV current method

The perturb and observe algorithm is the most popular method used to extract the MPP. This popularity is due to its simplicity, ease and it requires only few parameters [13]. A working idea of this method depends on the periodically perturbing in the PV panel operating voltage. Since the PV panel is directly connected to a DC-DC power converter, then perturbation of the PV panel operating voltage is done by changing the duty cycle of the DC-DC convertor. Fig. 7 shows the flow chart of perturb and observe MPPT algorithm [12].

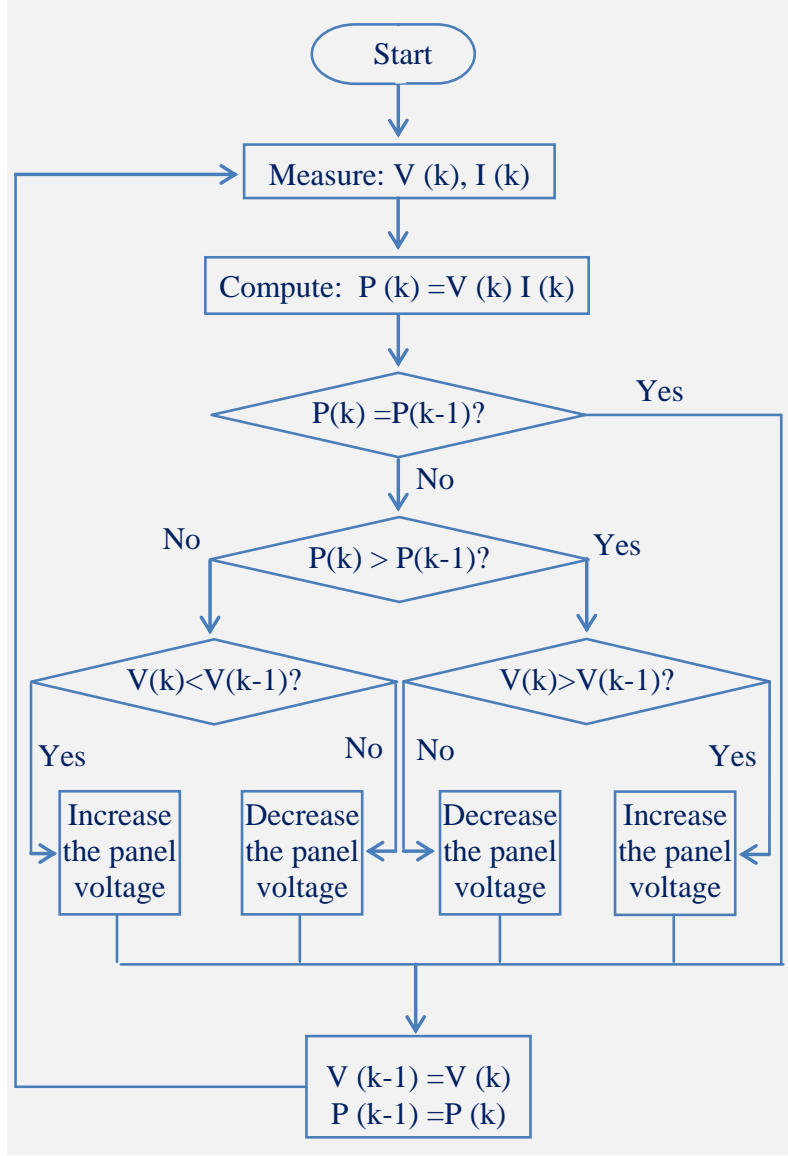

Fig. 7: Flowchart of P\&O MPPT algorithm [12]

\section{BUCK CONVERTER AS A CHARGER POWER CIRCUIT}

The step-down (Buck) DC-DC converter interfaces between the PV panel and the lead-acid battery as a charger power circuit to adjust the battery charging current. The diagram of the buck converter is shown in Fig. 8 [14].

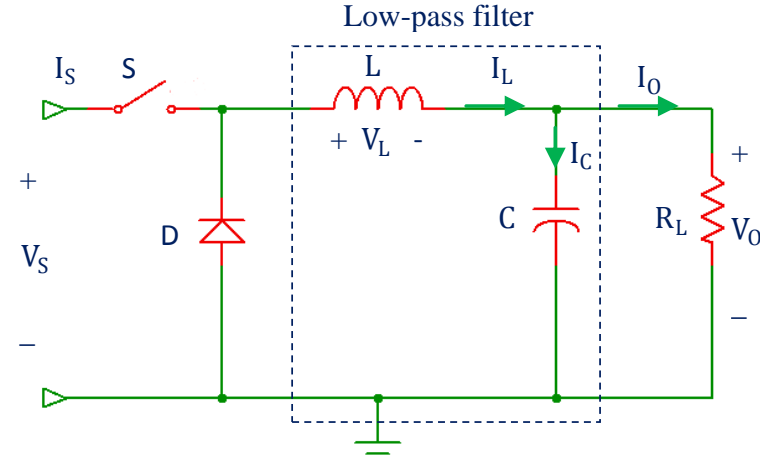

Fig. 8: Schematic diagram of a buck converter [14]

The design equations of the buck converter are presented from (12) to (15) [14].

$\mathrm{V}_{\mathrm{O}}=\mathrm{D} \mathrm{V}_{\mathrm{S}}$

Where:

$\mathrm{V}_{\mathrm{O}}$ : Output voltage of buck convertor $(\mathrm{V})$.

D: Duty cycle.

$\mathrm{V}_{\mathrm{S}}$ : Input voltage of buck convertor $(\mathrm{V})$.

The inductance and capacitance of buck converter filter are designed based on the following equations to operate in Continuous Current Mode (CCM).

$$
\begin{gathered}
\mathrm{C}_{\text {min }}=\frac{\mathrm{V}_{\mathrm{O}}(1-\mathrm{D})}{8 \Delta \mathrm{V}_{\mathrm{O}} \mathrm{Lf}_{\mathrm{S}}^{2}} \\
\mathrm{~L}_{\text {min }}=\frac{\mathrm{V}_{\mathrm{S}}}{8 \mathrm{f}_{\mathrm{S}} \mathrm{I}_{0, \text { min }}} \\
\mathrm{I}_{0, \text { min }} \geq \mathrm{I}_{\mathrm{LB}, \text { max }}
\end{gathered}
$$

Where:

$\mathrm{C}_{\min }$ : The minimum capacitance of buck converter to operate in $\mathrm{CCM}(\mathrm{F})$

$\Delta \mathrm{V}_{\mathrm{O}}$ : Ripple of output voltage of buck convertor $(\mathrm{V})$

$\mathrm{L}$ : Convertor inductance $(\mu \mathrm{H})$

$\mathrm{f}_{\mathrm{S}}$ : Switching frequency $(\mathrm{kHz})$

$\mathrm{L}_{\min }$ : Minimum inductance of buck converter to operate in $\mathrm{CCM}(\mu \mathrm{H})$

$\mathrm{I}_{0, \min }$ : Minimum output current to operate in CCM (A)

$\mathrm{I}_{\mathrm{LB}, \max }$ : Maximum boundary current of inductance (Average value) (A)

The buck convertor in this research, designed to operate on switching frequency $\left(f_{s}\right)$ of $50 \mathrm{kHz}$, in $\mathrm{CCM}$ as long as the charging current within the range between the greatest charging current (in this research, its take as C/12 $=200 / 12$ $\cong 16 \mathrm{~A}$ ) ( $\mathrm{C}$ is the nominal battery capacity in ampere-hours) to a value close to the trickle current (about $\mathrm{C} / 40=5 \mathrm{~A}$ ). When the charging current is less than this value $(\mathrm{C} / 40)$, the inductance current will become discontinuous. According to this and by applying equations (12)-(15), the determined values of inductance and capacitance of the buck converter filter are $15 \mu \mathrm{H}$ and $4.9 \mu \mathrm{F}$ respectively.

\section{DECREASED CHARGING CURRENT BASED ON SOC METHOD}

The aim of the decreased charging current method is to make the actual charging current closest to the maximum possible current as shown in Fig. 9 [15] [16]. It is observed that the maximum charging voltage or overcharging voltage set to $V_{g}$ is about $2.4 \mathrm{~V} /$ cell. The execution process of this charging method is described as follows: the initial charging current of the battery starts with the greatest charging rate $C_{a}$, then the 
alteration into $\mathrm{C}_{\mathrm{a}+1}$ by multiplying it by a reduction coefficient $\left(\beta=C_{n} / C_{n-1}\right)$ every time the battery voltage arrives to $V_{g}$. Then, the charging rate changes to $C_{a+2} \ldots . . C_{n}$ in role. This process is repeatedly continued till the maximum charging current reaches $\mathrm{C} / 100$, and the battery charging voltage rise higher than $2.4 \mathrm{~V} /$ cell (refers to a $100 \%$ state of charge) is reached. In that situation, the charging current has stayed to the least value known as $\mathrm{I}_{\text {trickle }}$ to the indemnity of the controlling unit power, depreciation and the self-discharge of the battery. The first value of the maximum charging current of the battery is renovated when a battery reachs the discharging condition.

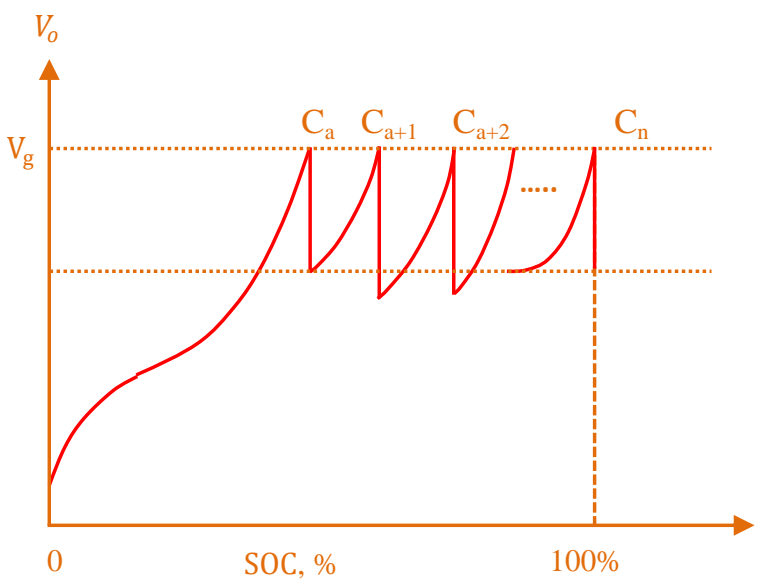

Fig. 9: Principle of decreased charging current $\left(V_{0}\right.$ is the battery voltage, $C_{a}, C_{a+1}, C_{a+2}, \ldots C_{n}$, are charging rates in $a, a+1, a+2 \ldots n$ hour; $V_{g}$ is the gassing voltage) [16]

For low panel output power, MPPT algorithm is done, maximizing the power converted to the battery. In respect of other states, the battery charging current is controlled to the maximum acceptable current.

The advantages of this method over traditional charging methods are: The method, comparatively makes the batteries reach full capacity in a short time without accurately gauging batteries current; also it reduces the current sensor accuracy required and the cost for circuitry. Furthermore, in contrast to voltage-regulation methods, as the proposed method is based on battery current regulation, it results in a uniform charging of all cells. Thus, it can be effectively used in large battery strings. For these reasons, this method increased the battery life time by restoring the maximum possible battery (SOC) in the shortest charging time.

The main drawback of this method is that the reduction coefficient $\beta$ chosen too high or low could result to batteries overcharge or not enough charge, which will adversely affect battery life [15] [16].

The charging algorithm flowchart is shown in Fig. 10. A set of variables are used to store the following parameters of the system operation:

- The minimum and maximum permissible battery voltage and current levels.

- The MPPT control action (variable B in Fig. 7, taking values 1 or 0 ), indicating whether the MPPT process must be performed or the charging current must be decreased (if $\mathrm{B}=1$ then MPPT is performed; except that, the charging current must be decreased where it is higher than the maximum required battery current). The maximum battery charging current is set to $\mathrm{C} / 12$ to protect the battery from overheating. The minimum current is set to $\mathrm{C} / 100$, corresponding to a battery $100 \%$ state of charge, according to Fig. 3. When the battery is fully charged, the PV panel will feed the load directly and the battery charging current is regulated to $\mathrm{I}_{\text {trickle }}$ to compensate for the control system power consumption and the battery self-discharge.

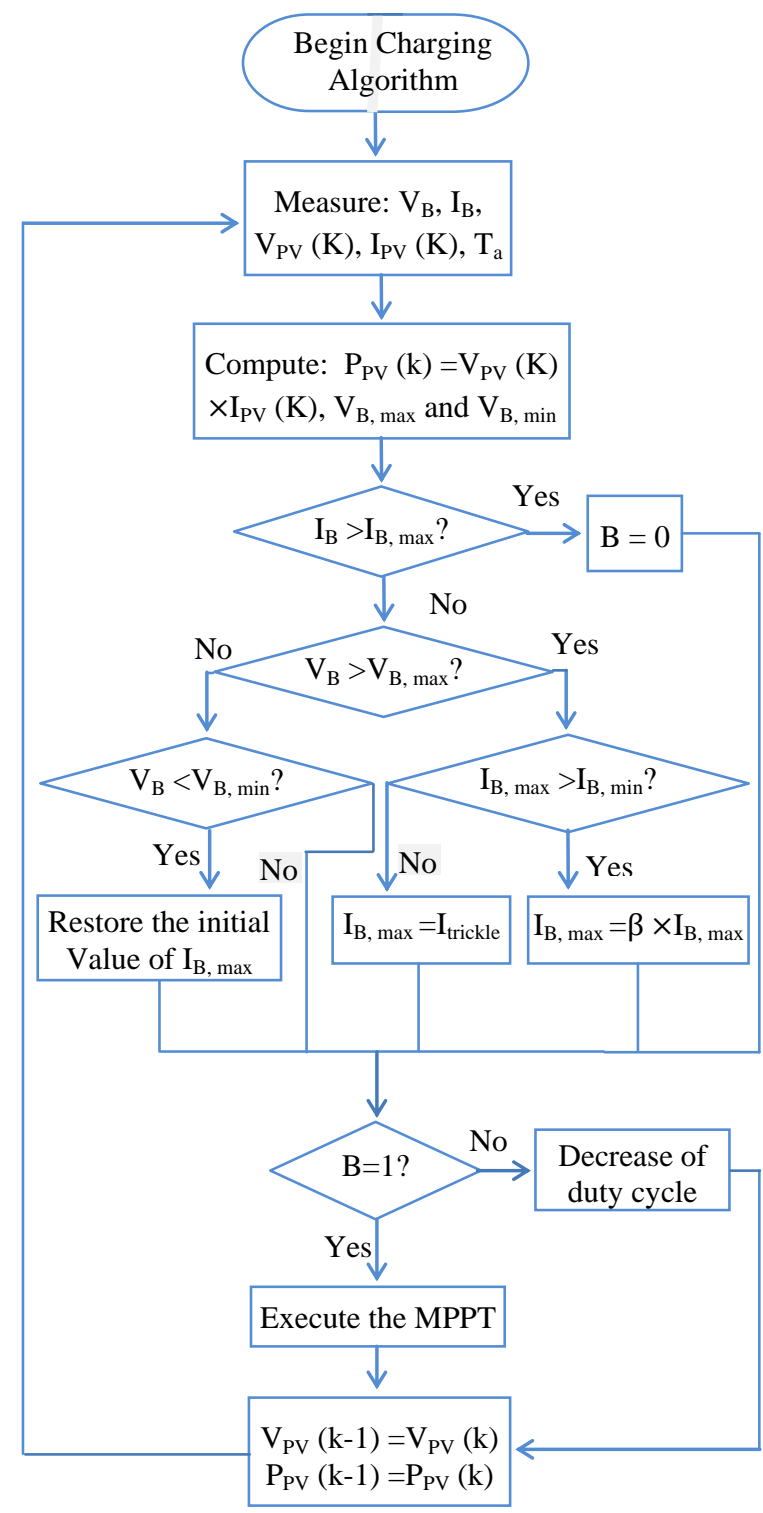

Fig. 10: Control algorithm flowchart of a lead-acid battery charging

The minimum and maximum battery voltage levels are then calculated as [15]:

$$
\begin{aligned}
& \mathrm{V}_{\text {bat,max }}=28.8+\left(\mathrm{T}_{\mathrm{a}}-25\right) \mathrm{N}_{\mathrm{C}} \gamma \\
& \mathrm{V}_{\text {bat,min }}=25.4+\left(\mathrm{T}_{\mathrm{a}}-25\right) \mathrm{N}_{\mathrm{C}} \gamma
\end{aligned}
$$

Where:

$\mathrm{T}_{\mathrm{a}}$ : Ambient temperature $\left({ }^{\circ} \mathrm{C}\right)$

$\gamma$ : Temperature compensation coefficient $\left(\gamma=3.5 \mathrm{mV} /{ }^{\circ} \mathrm{C} /\right.$ cell $)$ $\mathrm{N}_{\mathrm{C}}$ : Number of cells of the battery stack $\left(\mathrm{N}_{\mathrm{C}}=12\right.$ cell $)$ 
The initial values of set of variables are given in Table 2 [15].

Table 2, Initial Values of the Program Variables [15]

\begin{tabular}{|c|c|}
\hline Variable & Initial value \\
\hline Minimum battery current $\left(\mathrm{I}_{\mathrm{B}, \min }\right)$ & $\mathrm{C} / 100$ \\
\hline Maximum battery current $\left(\mathrm{I}_{\mathrm{B}, \max }\right)$ & $\mathrm{C} / 12$ \\
\hline Trickle current $\left(\mathrm{I}_{\text {trickle }}\right)$ & $\mathrm{C} / 100=2 \mathrm{~A}$ \\
\hline Minimum battery voltage $\left(\mathrm{V}_{\mathrm{B}, \min }\right)$ & $25 \mathrm{~V}$ at $25^{\circ} \mathrm{C}$ \\
\hline Maximum battery voltage $\left(\mathrm{V}_{\mathrm{B}, \max }\right)$ & $28.8 \mathrm{~V}$ at $25^{\circ} \mathrm{C}$ \\
\hline MPPT control action, $\mathrm{B}$ & 1 \\
\hline
\end{tabular}

\section{PROPOSED SYSTEM DESCRIPTION}

The block diagram of the proposed PV battery charging system is shown in Fig. 11. This PV system consists of eight major parts: (1) solar panels, (2) buck converter circuit as the charger power circuit, (3) Voltage and current sensors of panel and battery, which achieved by means of a voltage divider and a Hall-effect current sensors respectively, (4) PIC18F45K22 microcontroller to control the power MOSFET switching duty cycle on the buck converter, (5) gate drive circuit, (6) rechargeable lead-acid battery, (7) resistive load and (8) Liquid Crystal Display (LCD), which informs the user about various parameters of the system operation, for example, it shows the value of charge current.

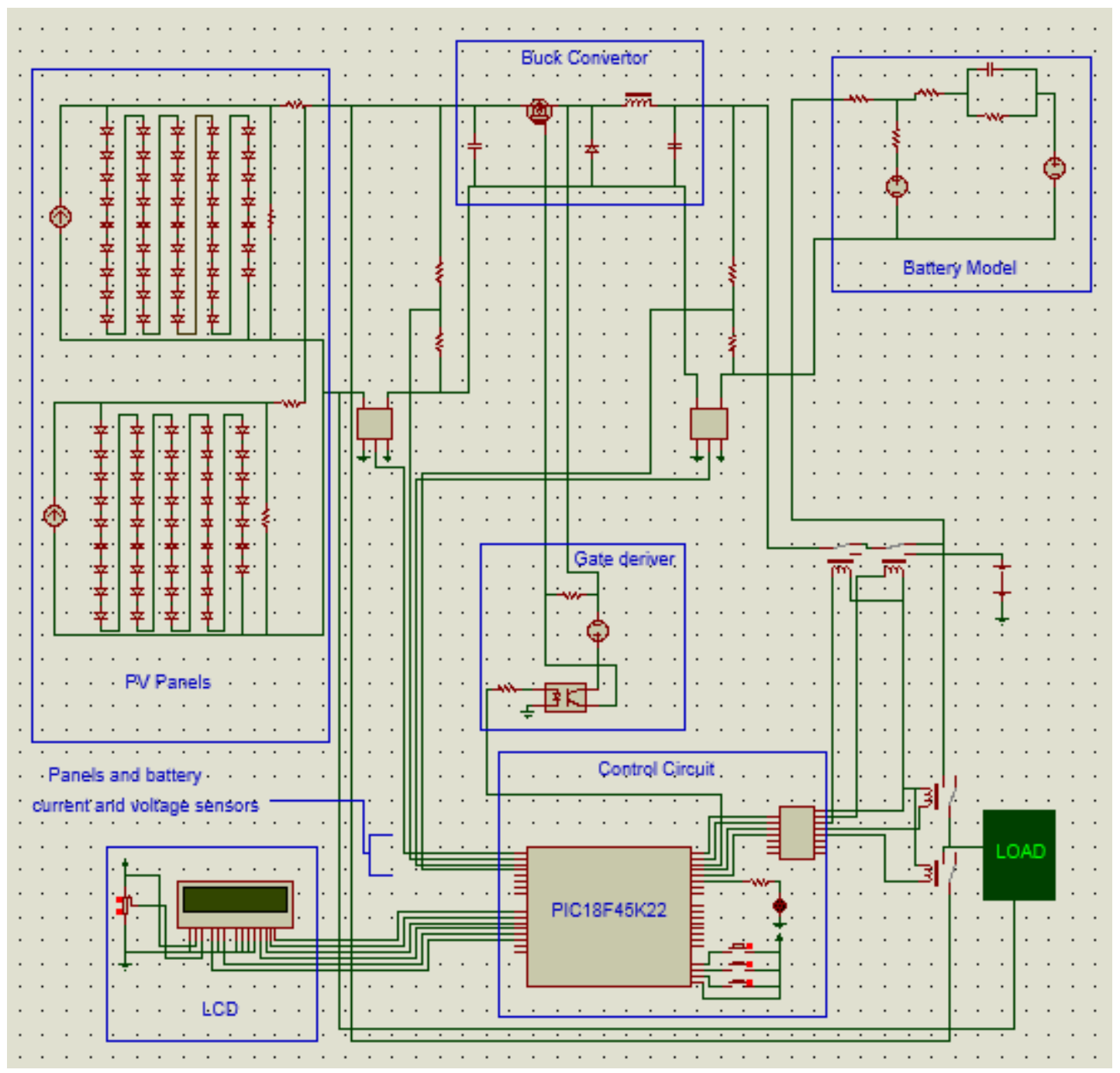

Fig. 11: Schematic diagram of the proposed PV battery charger system

Practical charger circuit that builds on laboratory shown in

Fig. 12. 


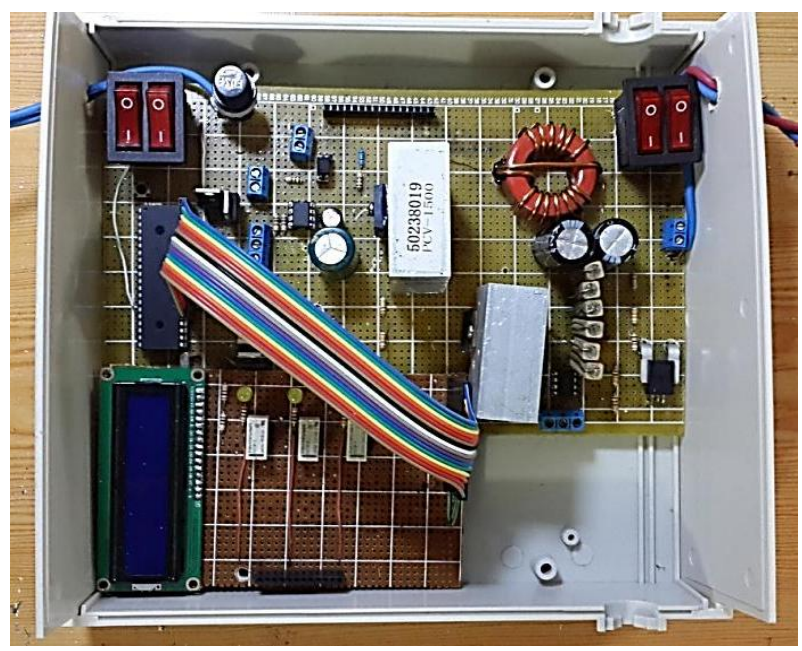

Fig. 12: Practical charger circuit that builds in laboratory

Fig. 13 shows the practical components of the overall proposed PV charger system

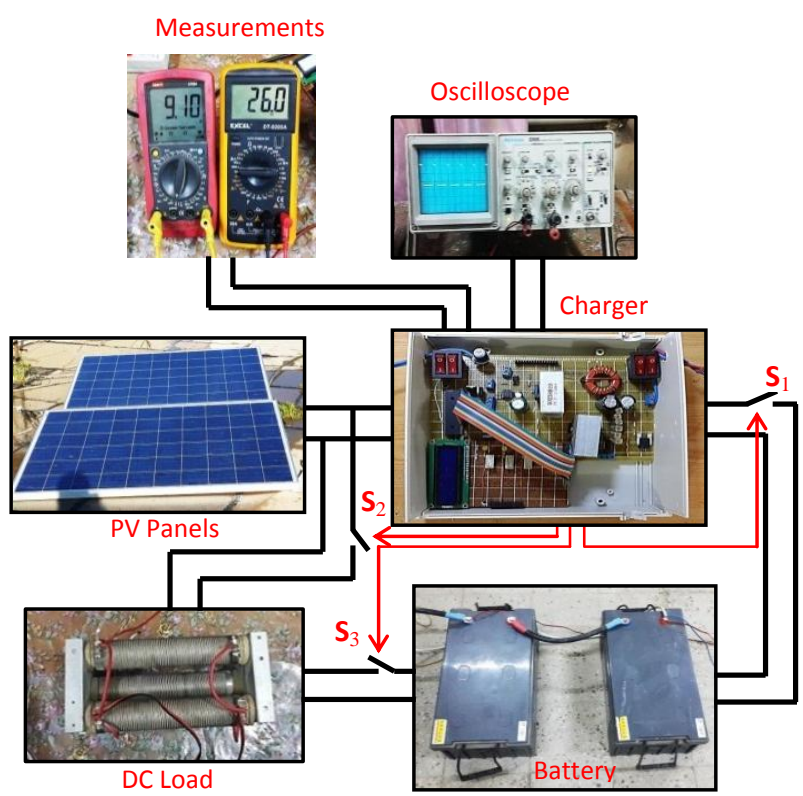

Fig. 13: Practical components for overall proposed PV charger system

\section{SIMULATION RESULTS}

Table 3 shows the simulation parameter of the PV panel that was used in the simulation program (Proteus).

Table 3, Simulation Parameters of PV Panel

\begin{tabular}{|c|c|}
\hline Parameter & Value \\
\hline Peak Power, PMPP (W) & 481 \\
\hline Peak power current, IMPP (A) & 15.8 \\
\hline Peak power voltage, VMPP (V) & 30.44 \\
\hline Open circuit voltage, VOC (V) & 38.2 \\
\hline Short circuit current, ISC (A) & 16.4 \\
\hline
\end{tabular}

Fig. 14 presents the PV output current, power versus the output voltage for the variable load for the PV panel that used in this research

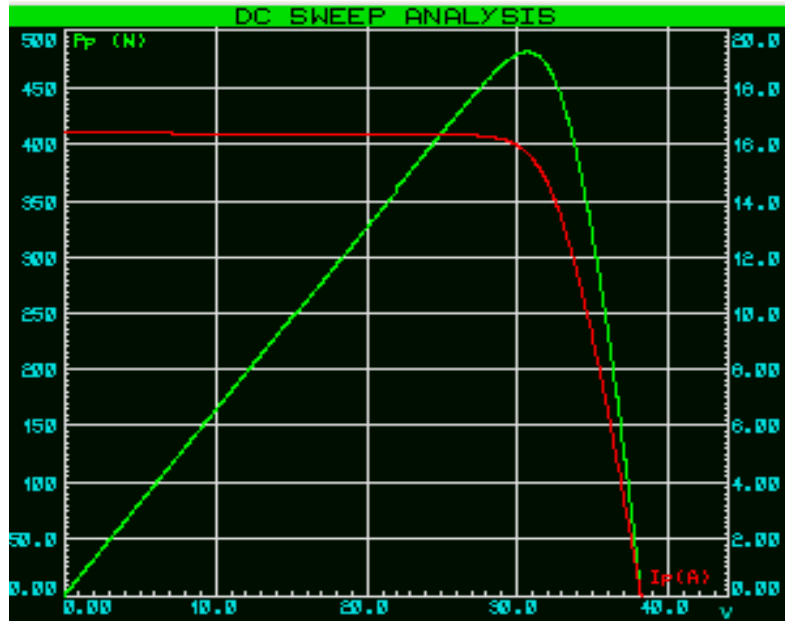

Fig. 14: PV output current, power versus the output voltage to a variable load

The complete charging process can be divided into three main stages:

The first stage is the maximum charging current period, this stage will continue until the battery voltage reaches overcharging limit. Second stage is the period when the current is decreasing from greatest allowed current to the trickle current. The last stage represents the trickle charging current periods

Fig. 15 shows the charging current and voltage at the maximum charging stage. PV panel will be runs at maximum power point in this charging stage. Where, the output power, current and voltage of the panel are agreeing with that in the Table 3.

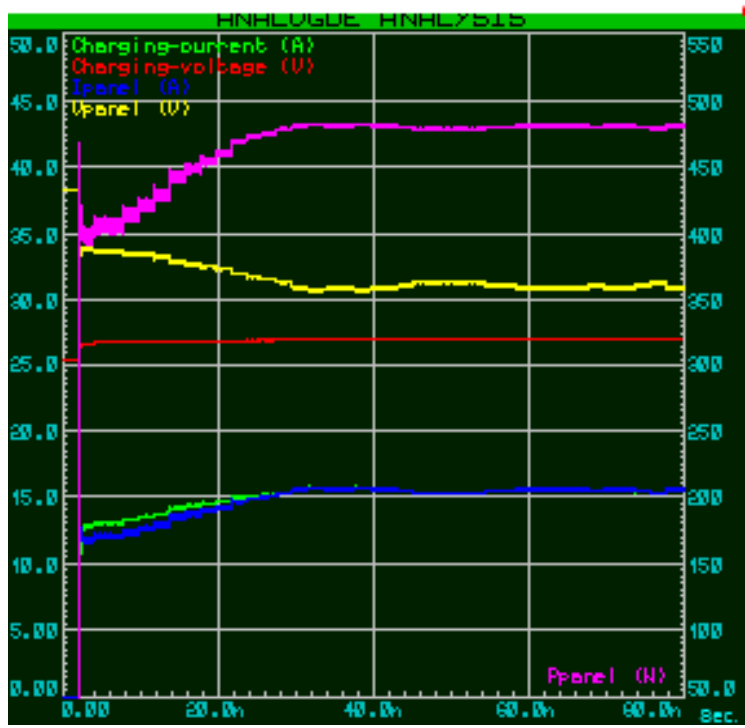

Fig. 15: The charging voltage and current at maximum charging stage

Fig. 16 shows the charging current at decreasing charging stage at reduction coefficient $(\beta)$ equal 0.99 . The current value that noted at each step that gassing voltage is reached programmed as a maximum current value for the next step. 


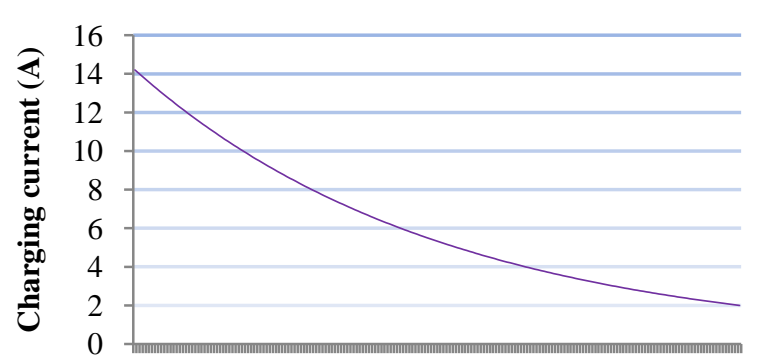

Steps of gassing voltage reaching

Fig. 16: The charging current at decreasing charging stage

Fig. 16 shows the charging voltage and current at trickle charging stage. As shown in this figure, the filter inductance will be operating in discontinues current mode (DCM) in this stage of charging.

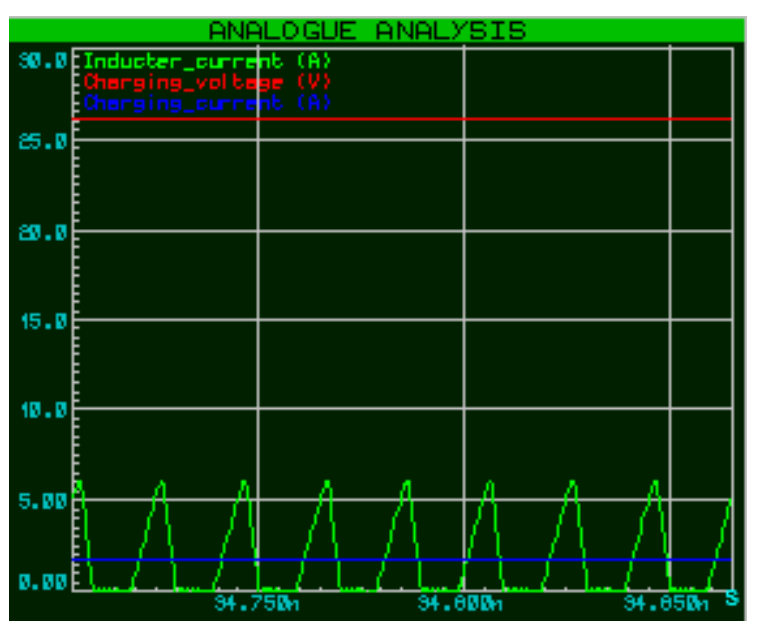

Fig. 16: The charging voltage and current at the trickle charging stage

\section{PRACTICAL RESULTS}

\subsection{MPPT Results}

The practical results of MPPT are executed at $745.7 \mathrm{~W} / \mathrm{m}^{2}$ and $22^{\circ} \mathrm{C}$ of radiation intensity and ambient temperature as shown in Fig. 17 and Fig. 18.

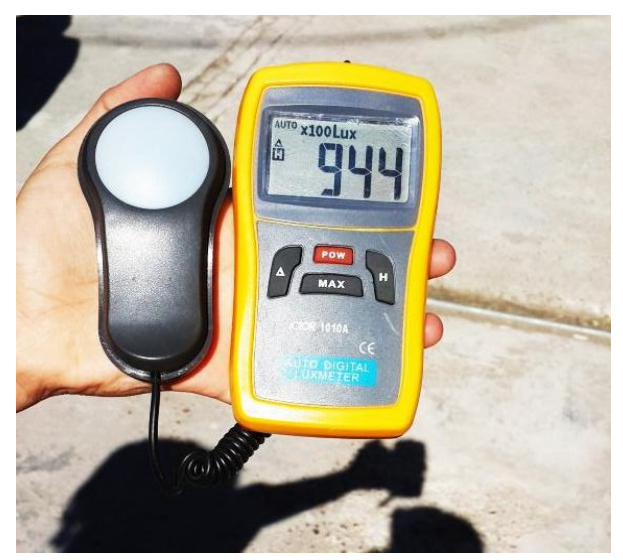

Fig. 17: Radiation intensity

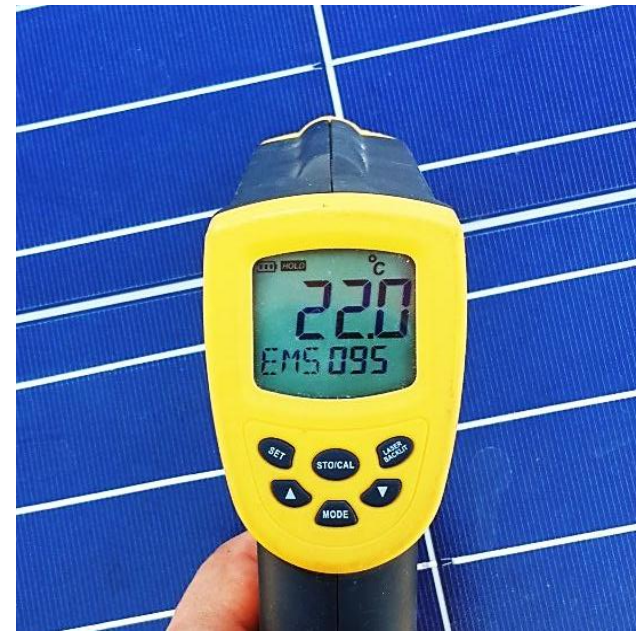

Fig. 18: ambient temperature

The open circuit voltage and short circuit current of the used two panels under $22^{\circ} \mathrm{C}$ and $745.7 \mathrm{~W} / \mathrm{m}^{2}$ are shown in Fig. 19.
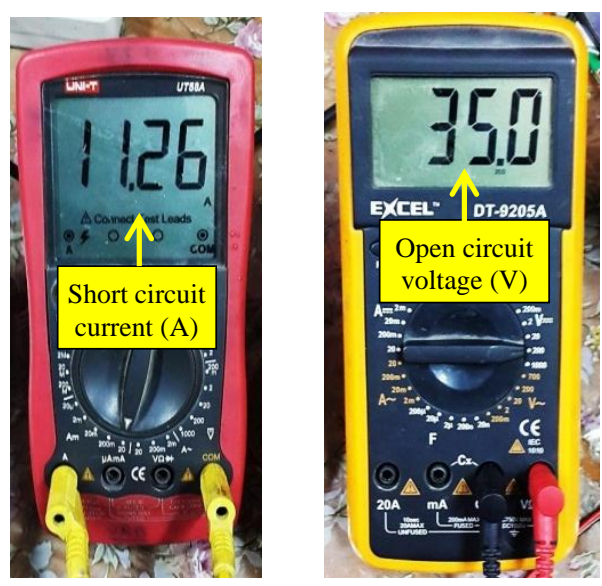

Fig. 19: Practical open circuit voltage and short circuit current of panels

The voltage and current at MPP under $22^{\circ} \mathrm{C}$ and $745.7 \mathrm{~W} / \mathrm{m}^{2}$ environment conditions are $26 \mathrm{~V}$ and $9.1 \mathrm{~A}$ respectively as shown in Fig. 20.

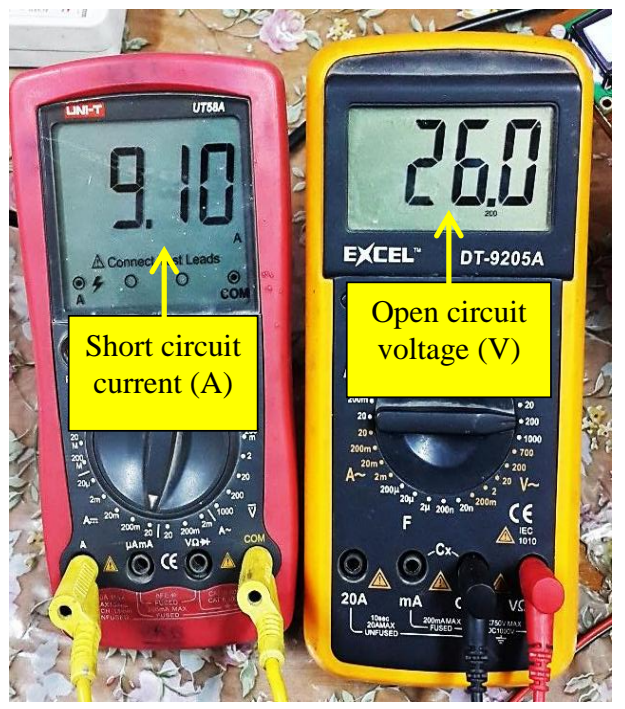

Fig. 20: Practical voltage and current at MPP of two panels 


\subsection{Buck Converter Results}

Fig. 21 and Fig. 22 show the practical voltage and current waveforms of this inductor in CCM;

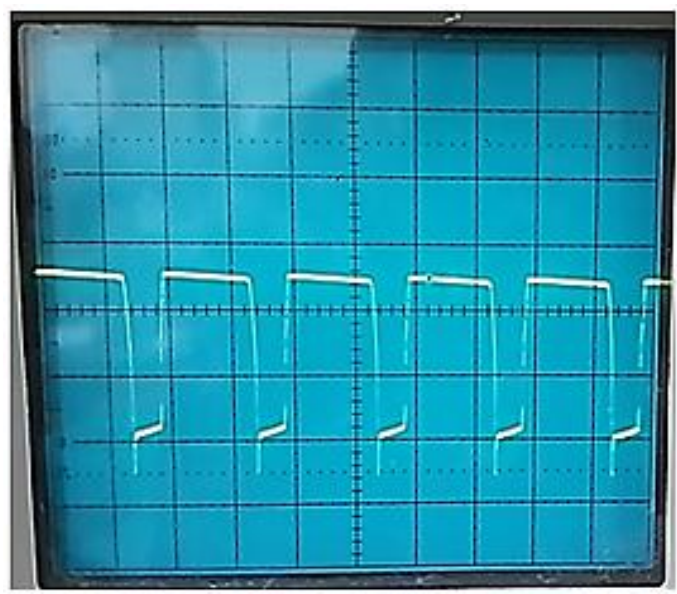

Fig. 21: Practical voltage waveform of inductor in CCM

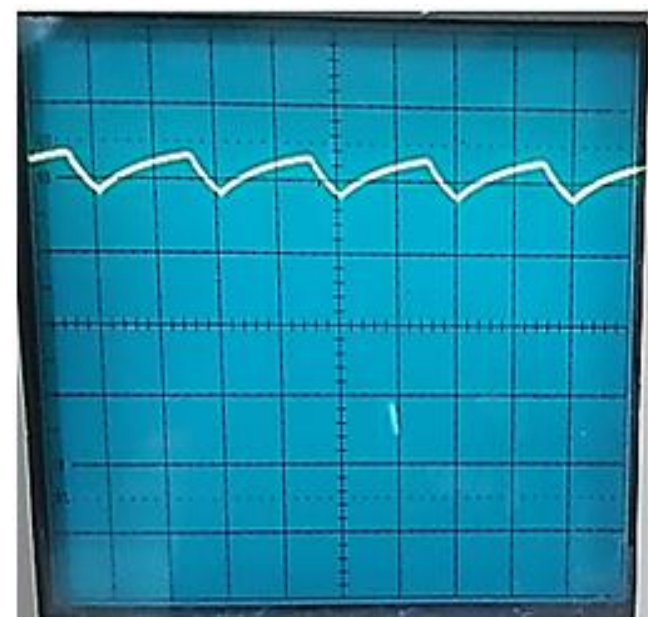

Fig. 22: Practical current waveform of inductor in CCM

Fig. 23 shows the practical charging current waveform

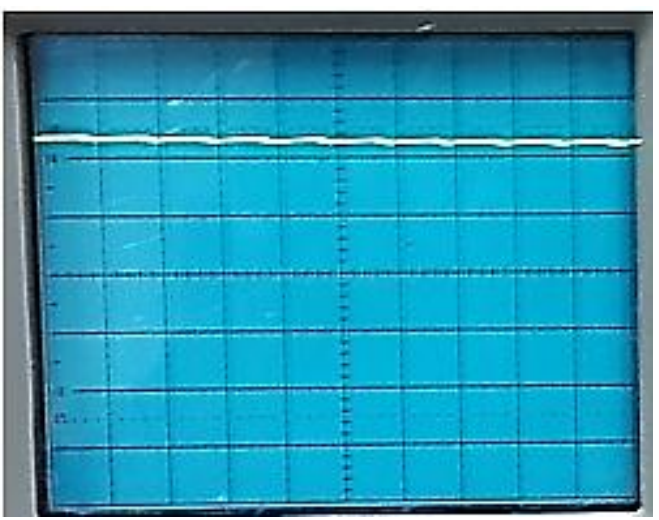

Fig. 23: Practical is charging current waveform

\subsection{Execution of Charging Process}

Fig. 24 shows the practical charging voltage and current at the maximum charging stage.

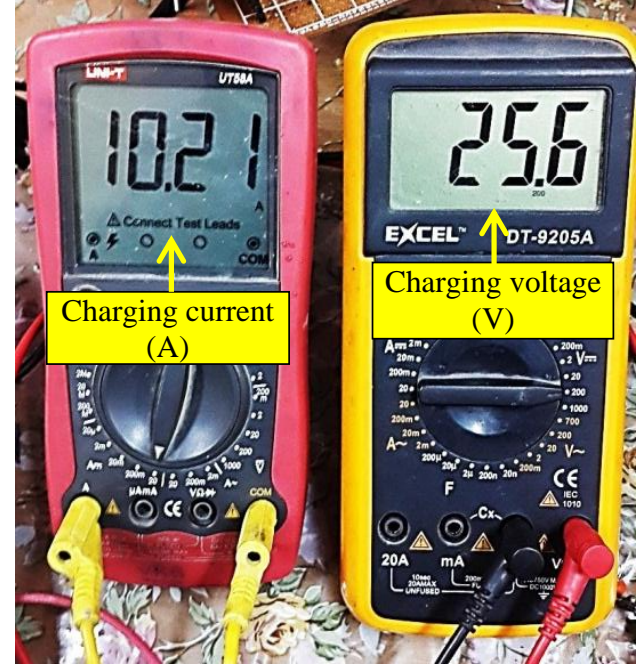

Fig. 24: Practical charging voltage and current at maximum charging stage

Fig. 25 shows the practical voltage and current at part of decreased charging stage.

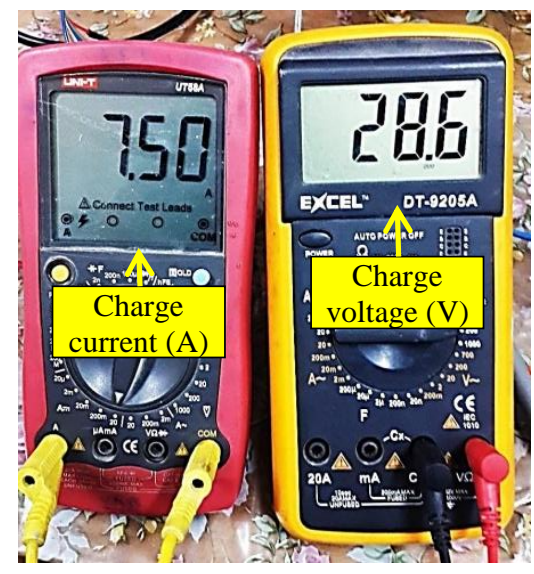

Fig. 25: Practical voltage and current at decreased charging stage

Fig. 26 shows the practical charging voltage and current at trickle charging stage.

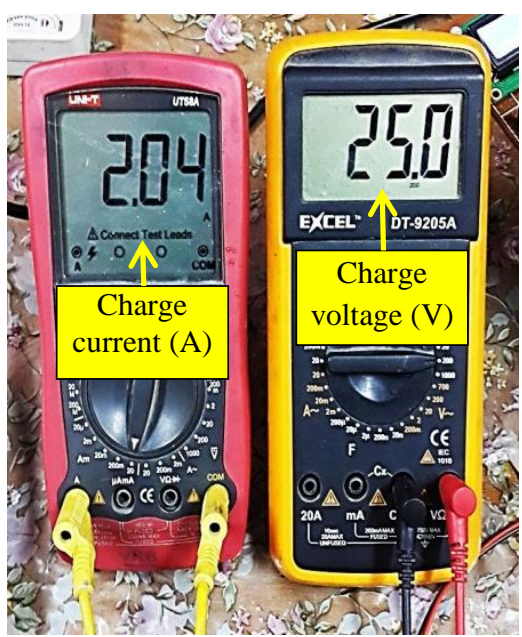

Fig. 26: Practical charging voltage and current at trickle charging stage 


\section{CONCLUSION}

Nowadays, as the environmental pollution and energy crisis is increasing seriously, photovoltaic power generating system will become more and more popular. However, in the photovoltaic system, the output energy of PV panel is uncertain and condition of using the battery is particular, which makes battery become an important part in affecting the lifespan of the whole photovoltaic power generating system. The overall cost of a stand-alone PV system can be reduced with proper battery-charging control techniques, which make full use of the output energy of PV module and to manage the battery efficiently, and to extend the life-span of the battery, under continuously varying atmospheric conditions.

Therefore, this work presents the design of an intelligent charger that controls the lead acid battery charging process and the correct use of the lead-acid battery supervising its discharge and also avoids the overcharging and gassing problems with lead-acid batteries. This charger increases the lifetime of the storage battery, which is the most expensive part of the solar system because it is required to be replaced in a short time as compared with the PV panels.

The advantages of the proposed charging method are:

- The control algorithm executes the P\&O maximum power point tracking function allowing, according to solar irradiance and temperature, transfer the maximum energy generated by photovoltaic panel to the battery. This $\mathrm{P} \& \mathrm{O}$ algorithm increases the efficiency power transfer in comparison to systems that have not an MPPT (direct connection), reducing the size and the cost of the PV panel.

- This method, relatively makes the battery reaches a full SOC in a short time.

- The battery-charging algorithm does not depend on accurate battery current measurements, thus reducing the current sensor accuracy required and subsequently the cost of the circuitry. Also, since it is based on battery current regulation, it can be effectively used in large battery strings.

Finally, the practical component of this system was carried out. All the components were interconnected and the solar battery charger prototype was tested. The close agreement between simulation and experimental work shows that the electrical models of the entire system accurately predict the system behavior. The battery charger allowed to correctly charging the lead-acid battery and during this process it was possible to see, through measurements and the LCD screen in real time, the various parameters of the system operation, for example, it shows the value of charge current and the maximum power transfer from the PV to the battery.

\section{REFERENCES}

[1] S. M. Çınar and E. Akarslan, "On the Design of an Intelligent Battery Charge Controller for PV Panels", University of Afyon Kocatepe, October 2012, Turkey, Journal of Engineering Science and Technology Review, pp. 30-34.

[2] Daoud and A. Midoun, "Fuzzy Control of a Lead Acid Battery Charger", Institut d'Electronique, ORAN, ALGERIE, 2005, J. Electrical Systems, pp. 52-59.

[3] Mohammed Shoaib and V Nagaraj, "Novel Battery Charging Control System for Batteries Using On/Off and
PWM Controllers for Stand Alone Power Systems", Manipal University, India, 2013, IOSR Journal of Electrical and Electronics Engineering, Vol. 6, pp. 44-52.

[4] David Linden and Thomas B. Reddy, "Handbook of Batteries". $3^{\text {th }}$ ed., 1995, ISBN 0-07 -135978-8, Printed in the United States of America.

[5] Shen Guo, "The Application of Genetic Algorithms to Parameter Estimation in Lead-Acid Battery Equivalent Circuit Models", A Thesis Presented to the University of Birmingham, 2010

[6] Ola Subhi Waheed Al-Qasem, (2012) "Modeling and Simulation of Lead- Acid Storage Batteries within Photovoltaic Power Systems", A Thesis Presented to the An-Najah National University, Palestine.

[7] Massimo Ceraolo, "New Dynamical Models of LeadAcid Batteries" IEEE Transactions on Power Systems, Vol. 15, No. 4, p.p.1184 -1190, November, 2000.

[8] Nazih Moubayed, Janine Kouta, Lebanese University Lebanon, Ali EI-AIi, Hala Dernayka and Rachid Outbib, Aix-Marseille III University, Marseille - France, "Parameter Identification of the Lead-Acid Battery Model", IEEE, 2008.

[9] Samer Said, Ahmed Massoud, Mohieddine Benammar and Shehab Ahmed, "A Matlab/Simulink-Based Photovoltaic Array Model Employing SimPowerSystems Toolbox", Qatar, 2012, Journal of Energy and Power Engineering6, pp. 1965-1975.

[10] Ansam Subhi Jabbar, "Investigation into Efficient Standalone Photovoltaic System Based on Iraq Climate", Iraq, April, 2014, A Thesis Presented to the University of Technology.

[11] Shuhui Li, Senior Member, IEEE and Huiying Zheng, "Energy Extraction Characteristic Study of Solar Photovoltaic Cells and Modules", University of Alabama, Tuscaloosa, 2011.

[12] José Antonio Barros Vieira and Alexandre Manuel Mota, "Maximum Power Point Tracker Applied in Batteries Charging with Photovoltaic Panels", Portugal, http://www.intechopen.com.

[13] Mei Shan Ngan and Chee Wei Tan, "A Study of Maximum Power Point Tracking Algorithms for Standalone Photovoltaic Systems", Universiti Teknologi Malaysia, Malaysia, 2011, IEEE, pp. 22- 27

[14] Ned Mohan, William P. Robbins, University of Minnesota, Minnesota, Tore M. Undeland, Norwegian University of Science and Technology, Norway, "Power Electronic Converters, Applications, and Design", Third Edition, USA ISBN 978-0-471-22693-2 WIE ISBN 0-47 1-42908, 2003.

[15] E. Koutroulis and K. Kalaitzakis, "Novel Battery Charging Regulation System for Photovoltaic Applications", IEE, Technical University of Crete, Chania, Vol. 151, No. 2, P.P. 191-197, 2004.

[16] Tiezhou Wu, Qing Xiao, Linzhang Wu, Jie Zhang and Mingyue Wang, "Study and Implementation on Batteries Charging Method of Micro-Grid Photovoltaic Systems", Smart Grid and Renewable Energy, P.P. 324-329, 2011. 